Indonesian Journal of Islamic Communication, Vol. 2, No. 2, Desember 2019: 85-104

\title{
PESAN DAKWAH PADA PROGRAM DIALOG AGAMA ISLAM DI RADIO REPUBLIK INDONESIA KABUPATEN JEMBER
}

\author{
Diana \\ Program Studi Komunikasi dan Penyiaran Islam \\ Institut Agama Islam Negeri Jember
}

Diunggah 06 November / Direvisi 22 November / Diterima 6 Desember 2019

\begin{abstract}
Abstrac: Interactive dialogue through the radio has proven to be effective and efficient because it can be done anywhere and under any conditions. Given that the radio function is flexible, it can be carried everywhere, especially now that there is a streaming radio found on all android mobile phones. It is the same with Radio Republik Indonesia in Jember Regency, which has an Islamic Dialogue Broadcast program that exists since Radio Republik Indonesia was established, until now. This event was much liked and received a positive response from the public. Through this event, listeners can have a direct dialogue with the preacher who fills the event, about problems that occur both to himself, his family or the surrounding environment. The focus of this research is: (1) What are the characteristics of propaganda messages produced at Islamic religious dialogue programs on Radio Republik Indonesia, Jember Regency. (2) How is the production of da'wah messages at the Islamic dialogue program on Radio Republik Indonesia Jember Regency? The research objectives are (1) understanding the characteristics of preaching messages produced at Islamic religious dialogue programs on Radio Republik Indonesia Jember Regency (2) Understanding the process of producing propaganda messages at Islamic religious dialogue programs at Radio Republik Indonesia Jember District. This study uses a qualitative phenomenological approach. The research findings show that: (1) Da'wah messages packaged in the form of interactive dialogues through the Islamic Dialogue Program on Radio Republik Indonesia Jember Regency, get a good response from the community. This is evident, with the number of trends in listeners and listeners who respond when the dialogue takes place. This response is not only through telephone lines but also via SMS, what's up and Facebook and letters. (2) Problems presented by the community include issues of worship, economics, marital relations, the problem of drugs and how to understand ikhtilaf or differences in society. (3) The program runs from 05.00 to $06.00 \mathrm{WIB}$, allowing listeners to enjoy it, considering that this time is a relaxing time for some people, while for housewives and careers there is a time to prepare breakfast for the family. While the radio is an effective and flexible media that can be heard anywhere, both while in the room, while cooking, even in a vehicle.
\end{abstract}

Keywords; Pesan Dakwah, Dialog Agama

Korespondensi: Diana

Pascasarjana IAI Jember

Dianadin66@gmail.com 


\section{A. PENDAHULUAN}

Pesatnya perkembangan teknologi informasi dan komunikasi saat ini, tidak menggeser peran radio sebagai media populer yang dipilih sekelompok masyarakat untuk menyebarkan informasi kepada khalayak. Justru, radio semakin eksis. Bahkan, stasiun radio semakin kreatif dengan mengembangkan saluran streaming melalui internet, sehingga memudahkan pendengarnya memutar siaran kesukaannya dimanapun mereka berada, sekalipun berada di luar negeri. ${ }^{1}$

Ada beberapa faktor mengapa radio begitu populer di kalangan masyarakat. Pertama, harga radio yang murah dan terjangkau oleh hampir semua kalangan. Kedua, radio bersifat praktis, bisa dibawa kemana-mana, apalagi di era teknologi saat ini, radio bisa didengarkan melalui bandphone. Ketiga, jangkauan transmisi yang cepat dan luas, dan terakhir, memungkinkan adanya dialog interaktif antara penyiar dan pendengar. Faktor-faktor inilah yang menjadi alasan hampir seluruh lapisan masyarakat termasuk yang tinggal di daerah terpencil dapat mendengarkan radio. $^{2}$

Radio telah menjalani proses perkembangan yang cukup lama sebelum menjadi media komunikasi massa seperti dewasa ini. Sejak awal ditemukan oleh Donald McNicol dalam bukunya "Radio's Conquest of Space"menyatakan bahwa "terkalahkannya ruang angkasa oleh radio" (the conquest of space of radio) dimulai pada tahun 1802 oleh Dane, yang merupakan karya yang sangat sederhana, yakni ditemukannya suatu penerimaan pesan (message) dalam jarak pendek dengan menggunakan kawat beraliran listrik. ${ }^{3}$

Sejak itulah, radio akhirnya dikembangkan oleh Dr. Lee De Forest, ilmuwan Amerika Serikat yang dijuluki "the father of radio" pada tahun 1916. Dan pada tahun 1919, Dr. De Forest menyiarkan berita radio. Sedangkan yang melakukan eksperimen menyiarkan musik ialah Dr. Frank Conrad seorang ahli pada Westinghouse Company di Pittsburgh Amerika Serikat. Dan akhirnya, radio terus dikembangkan oleh negara-negara lainnya seperti Inggris, Perancis, Uni Soviet, Jepang dan Republik Rakyat Cina (RRC). ${ }^{4}$

Di Indonesia, radio siaran dibawa oleh pemerintah Belanda saat menjajah Indonesia. Radio pertama di Indonesia bernama Bataviase Radio Vereniging (BRV) yang resmi didirikan pada 16 Juni 1925 atau lima tahun setelah Amerika Serikat menyiarkan berita radio pertama kali. BRV yang berstatus swasta telah menjadi cikal bakal berdirinya radio di Indonesa. Antara lain, Nederlandsch Indische Radio Omroep Mij (NIROM) di Jakarta, Bandung dan Medan. Dan

\footnotetext{
${ }^{1}$ Din Wahid dan Jamhari Makruf, Suara Salafisme, (Jakarta: Prenamedia, 2009), Prolog.

${ }^{2}$ Din Wahid dan Jamhari Makruf, Suara Salafisme,...9-10.

${ }^{3}$ Onong Uchjana Effendy, Radio Siaran Teori dan Praktek, (Bandung: Mandar Maju, 1991),21.

${ }^{4}$ Onong Uchjana Effendy, Radio Siaran,...22.
} 
Solossche Radio Vereniging (SRV) di Surakarta. Radio inilah yang menjadi pelopor berdirinya radio-radio yang ada saat ini di Indonesia. ${ }^{5}$

Siaran radio tidak hanya menyajikan lagu-lagu atau hiburan semata, tetapi juga mengupas berbagai isu strategis, mulai dari ekonomi, budaya, pendidikan, hukum dan politik. Radio tidak hanya menjadi sesuatu yang pasif yang hanya bisa didengarkan saja, namun tersaji juga acara dialog interaktif yang memungkinkan pendengarnya berdialog dengan narasumber melalui telepon. Kemampuan inilah yang menjadi salah satu alasan mengapa di era informasi, radio tetap menjadi pilihan masyarakat.

Neilsen, suatu perusahaan yang bergerak di bidang informasi global dan berfokus pada suatu penelitian terhadap berbagai media mencatat, tren konsumsi masyarakat terhadap radio berada di atas suratkabar, tabloid maupun majalah. Radio menempati urutan ketiga, di bawah televisi dan internet. Ternyata, pesatnya pertumbuhan internet di era informasi tidak menyebabkan pendengar meninggalkan radionya atau menyebabkan jangkauan pendengar radio menjadi rendah.

Berdasarkan hasil riset yang dilakukan Neilsen. Secara keseluruhan, konsumsi media di kota-kota baik di Jawa maupun Luar Jawa menunjukkan bahwa Televisi masih menjadi medium utama yang dikonsumsi masyarakat Indonesia, disusul oleh Internet, Radio, Suratkabar/Koran, Tabloid dan Majalah. Namun ketika dilihat lebih lanjut, ternyata terdapat perbedaan yang sangat menarik antara pola konsumsi media di kota-kota di luar Jawa. Konsumsi media televisi lebih tinggi di luar Jawa. ${ }^{6}$

Tabel 1. Rating media konsumsi masyarakat menurut Nielsen

\begin{tabular}{|l|l|l|}
\hline \multirow{2}{*}{ Nama Media } & \multicolumn{2}{|l|}{ Persentase Konsumsi } \\
\cline { 2 - 3 } & Pulau Jawa & Luar Pulau Jawa \\
\hline Televisi & $95 \%$ & $97 \%$ \\
\hline Internet & $33 \%$ & $32 \%$ \\
\hline Radio & $20 \%$ & $37 \%$ \\
\hline Suratkabar/Koran & $12 \%$ & $26 \%$ \\
\hline Bioskop & - & $11 \%$ \\
\hline Tabloid & $6 \%$ & $9 \%$ \\
\hline Majalah & $5 \%$ & $5 \%$ \\
\hline
\end{tabular}

${ }^{5}$ Onong Uchjana Effendy, Radio Siaran,...54.

${ }^{6}$ www.nielsen.com/id/en/press-room/konsumsi-media-lebih-tinggi-luar-jawa.html. (27 maret 2018) 
Tabel di atas menyebutkan tingkat konsumsi masyarakat terhadap media yang dikonsumsinya setiap saat. Tabel ini menunjukkan bahwa Radio masih senantiasa berada di hati pendengarnya dan masih menjadi pilihan masyarakat di era informasi yang serba canggih. Hal ini tentunya tak terlepas dari ciri khas siaran radio. Sebagai media elektronik yang sifatnya audial, siaran radio dilakukan dengan menggunakan bahasa lisan dan bersifat santai. Orang bisa menikmati acara siaran radio sambil makan, sambil tidur-tiduran, sambil bekerja, bahkan sambil mengemudikan mobil. Tidak demikian dengan media massa lainnya.

Karena masifnya penggunaan radio dan luasnya jangkauan radio, radio digunakan oleh kelompok masyarakat untuk kepentingan tertentu. Pada masa Orde Baru, Radio Republik Indonesia digunakan oleh pemerintah untuk menyosialisasikan kesuksesan pembangunan yang dilakukan oleh pemerintah. Pemerintah juga memonopoli penyebaran berita yang disampaikan kepada masyarakat melalui Radio Republik Indonesia yang harus di-relay oleh semua radio swasta. Menjelang jatuhnya Orde Baru, tuntutan reformasi di bidang hukum dan politik disampaikan melalui radio hingga jatuhnya pemerintah Orde Baru. ${ }^{7}$

Radio digunakan sebagai media yang cukup efektif untuk berdakwah. Seperti munculnya radio dakwah Salafi di beberapa kota di Indonesia yang memunculkan ketegangan, terutama antara kelompok Muslim tradisonal dan Salafi. Salah satu penyebab utama dari ketegangan ini adalah kritik Salafi terhadap praktik-praktik keagamaan yang dilakukan oleh kelompok Muslim tradisionalis yang dianggap sebagai bid'ah. Akibatnya, ketegangan yang mengarah ke konflik sosial terjadi di beberapa kota, seperti Cirebon, Ciamis (Jawa Barat), Gresik (Jawa Timur), dan Mataram (Nusa Tenggara Barat). ${ }^{8}$

Dakwah melalui radio terus berkembang. Radio Republik Indonesia (RRI), baik di pusat maupun di daerah menyediakan waktu siaran yang cukup memadai pada pagi hari setelah shalat Subuh. Da’i kondang seperti K.H. Kosim Nurseha menjadi penceramah tetap di RRI pusat. Pada akhir tahun 1980-an, Radio al-Thahiriyah dan asy-Syafi'iyah muncul dengan porsi dakwah yang lebih besar. meskipun bukan radio dakwah, kedua stasiun radio ini bisa dijadikan sebagai tonggak radio bernuansa religi. Sampai saat ini hampir semua radio menyediakan jam siar yang cukup besar untuk dakwah, terutama menjelang shalat Maghrib dan sehabis shalat Subuh. ${ }^{9}$

Jurgen Hubermas, filsuf dan sosiolog Jerman mengatakan, terkait dengan munculnya berbagai arena baru di mana masyarakat dari berbagai kelompok dan latar belakang yang berbeda dapat berdiskusi dengan bebas, menyampaikan keluhan dan perasaan, mengutarakan

\footnotetext{
${ }^{7}$ Din Wahid dan Jamhari Makruf, Suara Salafisme,...2.

${ }^{8}$ Din Wahid dan Jamhari Makruf, Suara Salafisme,...3.

${ }^{9}$ Din Wahid dan Jamhari Makruf, Suara Salafisme,...4.
} 
pendapat dan kritik terhadap kebijakan pemerintah, dan lain-lain. Keberadaan ruang publik dalam hal ini radio mencerminkan adanya partisipasi masyarakat dalam sistem pemerintahan yang demokratis, menjadi bagian dari civil society, dan karenanya tidak boleh dikontrol dan diintervensi oleh pemerintah. ${ }^{10}$ Kaitan dengan hal ini, agama muncul di ruang publik, disiarkan dan didiskusikan melalui media-media, seperti radio dan televisi dengan menghadirkan ustadz dan ustadzah yang berkompeten. Beberapa program dikemas secara interaktif agar pendengar bisa bertanya langsung kepada narasumber.

Narasumber yang berperan dalam aktivitas dakwah disebut da'i atau muballigh. Da’i adalah pelaku dakwah yakni orang yang menjalankan aktivitas dakwah. Tugas da'i adalah mengajak manusia untuk menjalankan perintah Allah dan Rasul-Nya. Luasnya cakupan pelaksanaan ajaran agama di era global saat ini, mengharuskan dakwah dilakukan dengan pembagian bidang garap, sehingga yang berperan dalam aktivitas dakwah tidak hanya da;'i atau ulama yang paham tentang ajaran agama, tetapi juga pihak-pihak yang memiliki keahlian lain yang dapat mendukung proses dakwah. ${ }^{11}$

Untuk melakukan dakwah dengan baik, maka seyogyanya subyek dakwah harus memenuhi syarat-syarat tertentu, meliputi penampilan fisik, pengetahuan dan integritas moral. ${ }^{12} D a ’ i$ seyogyanya harus berpenampilan rapi sesuai dengan situasi dan kondisi. Da’ $i$ juga harus memiliki pengetahuan tentang dakwah, yakni tentang kondisi obyek dakwah, dasar hukum dan dasar pemikiran pentingnya dakwah, tujuan dakwah, materi dakwah, metode dakwah, media dan evaluasi dakwah. Disamping itu, da’i harus memiliki integritas moral, yakni, berkepribadian dan bermoral baik sebagaimana telah dicontohkan oleh Rasulullah. Ukuran integritas moral bagi seorang da’i harus mencontoh kepribadian Rasulullah, yang siddiq (jujur atau benar), amanah (terpercaya), tabligh (menyampaikan secara utuh), dan fathanah (cerdas cendekia). ${ }^{13}$

Dakwah melalui radio dewasa ini terus dilakukan dengan berbagai kemasan, salah satunya melalui dialog interaktif. Demikian pula halnya yang dilakukan Radio Republik Indonesia di Kabupaten Jember. Satu-satunya radio yang menyandang nama pemerintah ini secara intensif memiliki program siaran dakwah yang disiarkan pada jam santai, yakni setelah shalat Subuh dan menjelang Maghrib. Salah satu program siaran dakwah yakni Dialog Agama Islam yang berlangsung mulai pukul 05.00 sampai 06.00 WIB. Segmen pendengar dalam program ini adalah semua usia karena disiarkan melalui programa 1 dan programa 2. Program

\footnotetext{
${ }^{10}$ Din Wahid dan Jamhari Makruf, Suara Salafisme,...5.

${ }^{11}$ Ropingi el Ishaq, Ilmu Dakwah, (Malang: Madani, 2016),50.

${ }^{12}$ Ropingi el Ishaq, Ilmu Dakwah,...51.

${ }^{13}$ Ropingi el Ishaq, Ilmu Dakwah,...52.
} 


\section{Diana}

ini merupakan kerjasama dengan beberapa instansi keagamaan, diantaranya, Kementerian Agama Kabupaten Jember, Nahdatul Ulama (NU), Institut Agama Islam Negeri (IAIN) Jember dan beberapa pengurus dari organisasi masyarakat Muhammadiyah.

Narasumber berasal dari ketiga lembaga tersebut, yang tak lain adalah para ustadz. Total ustadz yang memberikan tausiyah atau pesan dakwah kepada pendengar Radio Republik Indonesia sebanyak 18 orang. Mereka secara bergantian akan menyampaikan pesan dakwah kepada pendengar dalam acara dialog agama Islam dengan materi sesuai dengan kemampuan masing-masing ustadz atau da'i. Materi dakwah meliputi masalah aqidah islamiyah, syari'ah atau hukum, masalah muamalah yang mencakup hubungan sesama makhluk untuk mengabdi kepada Allah dan masalah akhlak.

Acara dialog agama Islam yang dikemas melalui dialog interaktif ini selalu mendapatkan respon positif dari pendengar. Setiap harinya, ada puluhan pendengar yang berpartisipasi aktif dalam program ini, yang dibuktikan dengan jumlah respon pendengar melalui telepon, sms atau whatsapp pada nomor telepon studio Radio Republik Indonesia. Respon dari pendengar dicatat oleh pengarah acara untuk mengetahui tingkat pendengar acara ini sebagai bahan dasar evaluasi program yang dilakukan setiap tiga bulan sekali.

Respon pendengar bervariasi, ada yang sesuai dengan tema dakwah ada juga yang keluar dari tema. Masalah yang dikemukakan pendengar lebih banyak tentang masalah muamalah, yakni yang menyangkut hubungan dengan sesama makhluk, meliputi masalah politik, ekonomi, hubungan asmara, jual beli dan sebagainya. Bahkan, ada pendengar yang datang langsung ke studio untuk berdialog langsung dengan da’i dengan tujuan agar mendapatkan porsi waktu yang lebih banyak setelah acara dialog agama Islam selesai.

Berdasarkan catatan Pengarah Acara (PA) di Radio Republik Indonesia (RRI) Kabupaten Jember, partisipasi pendengar di Radio Republik Indonesia khusus program dialog agama Islam dalam kurun waktu tiga bulan, mulai Januari hingga Maret 2018, jumlah pendengar terus mengalami kenaikan.

Tabel 2. Tren pendengar selama tiga bulan

\begin{tabular}{|l|l|l|l|}
\hline $\begin{array}{l}\text { Jumlah Pendengar yang } \\
\text { Merespon }\end{array}$ & Keterangan \\
\hline April & Mei & Juni & $\begin{array}{l}\text { Tren pendengar yang merespon terus } \\
\text { meningkat. Mereka antusias dengan tema } \\
\text { yang seiring dengan permasalahan yang ada. } \\
\text { Apalagi, mereka bisa bertanya dan direspon } \\
\text { langsung oleh narasumber, baik melalui } \\
\text { telepon langsung atau melalui sms, } \\
\text { facebook dan what's up. }\end{array}$ \\
\hline 32 & 33 & 54 & \\
\hline
\end{tabular}


Ketertarikan peneliti terhadap program dialog agama Islam ini, untuk mengetahui bagaimana karakteristik pesan dakwah yang diproduksi program siaran dialog agama Islam yang disampaikan da’i. Sebab, tren pendengar dan yang meresponnya terus mengalami kenaikan. Tentunya, karakteristik pesan dakwah erat kaitannya dengan tujuan utama Radio Republik Indonesia dalam memproduksi program dialog agama Islam. Oleh sebab itu, peneliti juga ingin mengetahui bagaimana produksi pesan dakwah yang diinginkan oleh Radio Republik Indonesia dalam acara dialog agama Islam, yang melibatkan tim produksi siaran dialog agama Islam, mulai dari perencanaan siaran, penataan program, penata musik, penyiar dan operator siar/rekam.

\section{B. PEMBAHASAN}

Dalam penelitian terdahulu, telah dibahas beberapa tema yang dibahas hampir serupa dengan penelitian yang dilakukan oleh Eva Maghfirah dalam jurnalnya tentang Komunikasi Dakwah; Dakwah Interaktif Melalui Media Komunikasi. ${ }^{14}$ Dalam jurnal karya Eva Maghfiroh, Mahasiswi Institut Agama Islam Syarifuddin Lumajang meneliti tentang penggunaan teknologi informasi radio untuk menyampaikan pesan dakwah kepada khalayak. Radio menjadi media efektif dalam menyampaikan pesan karena memiliki kekuatan yang mampu menjangkau khalayak luas dalam waktu yang relatif singkat. Penelitian ini menggunakan teori empati dan homofili karena meneliti tentang dialog interaktif antara da'i dengan mad'u.

Sedangkan karya ilmiah berupa skripsi milik Mohammad Fajar, mahasiswa fakultas dakwah di Universitas Islam Bandung yang meneliti tentang Dakwah Melalui Radio ${ }^{15}$, berkesimpulan bahwa radio mengalami perkembangan yang cukup pesat di era teknologi informasi. Radio siaran sebagai penyalur informasi dan pembentuk pendapat umum menjadi pilihan seseorang atau kelompok untuk menyampaikan informasi kepada khalayak termasuk menyampaikan pesan dakwah. Metode penelitian yang digunakan, yaitu analisis program siar dakwah radio MQ FM Bandung.

Penelitian yang ketiga, yakni tentang Pesan-pesan Dakwah Dalam Bahasa Tutur. ${ }^{16}$ karya H. Hikmat yang merupakan seorang Dosen UIN SGD Bandung menyimpulkan bahwa pesanpesan dakwah oleh seorang da’i menggunakan bahasa lisan dilakukan dalam kontrusi bahasa tutur kepada mad'unya. Kontrusi bahasa tutur merupakan bentuk tranmisi, transaksi dan

\footnotetext{
${ }^{14}$ Eva Maghfiroh. Komunikasi Dakwah; Dakwah Interaktif Melalui Media Komunikasi. (Lumajang: E-Journal Institut Agama Islam Syarifuddin. 2016)

${ }^{15}$ Mohammad Fajar Shiddiq, Dakwah Melalui Radio (Bandung: Karya Ilmiah Fakultas Dakwah, Universitas Islam Bandung. 2015).

${ }^{16}$ H. Hikmat. Pesan-Pesan Dakwah Dalam Bahasa Tutur. (Bandung: E-Journal Universitas Islam Negeri SGD. 2011).
} 
transformasi dari nilai-nilai yang sesuai dengan ajaran Islam. Sekalipun pesan-pesan dakwah dalam bahasa tutur merupakan bingkai budaya yang ada dalam masyarakat, namun tetap tidak keluar prinsip-prinsip qaulan syadidan, balighan, ma'rufan, kariman, layyinan dan qoulan maysuran. Pesan-pesan dakwah akan melekat sebagai teladan terhadap pribadi da’i. Oleh karena itu, kredibilitas da'i merupakan hal terpenting diterimanya dakwah seorang da’i oleh mad'unya. Teladan dari da’i sangat penting untuk keberhasilan dakwah yang dilakukan sang da’i.

Ketiga penelitian tersebut memiliki kesamaan dengan tesis peneliti adalah (1) samasama meneliti tentang dakwah melalui dialog interaktif di radio, (2) meneliti tentang dakwah melalui radio, (3) mengkaji tentang da’i dalam bertutur kata menyampaikan tausiyahnya, yang tidak boleh terlepas dari ajaran Islam. Dimana perkataan yang lemah lembut dan tidak mengandung provokasi harus diterapkan.

Sedangkan perbedaan penelitian ini dengan ketiga penelitian tersebut, terletak pada: Pertama, penelitian yang dilakukan Eva Maghfiroh mengkaji tentang obyek dakwah atau mad'u, sedangkan penelitian tesis ini meneliti tentang da’i.

Kedua, perbedaan penelitian yang dilakukan oleh Mohammad Fajar Siddiq ini membahas tentang efektivitas dakwah melalui radio, sedangkan peneliti melakukan penelitian tentang program siaran di radio yang dikemas dalam acara dialog interaktif.

Ketiga, pembahasan dan kajian dalam jurnal yang diteliti oleh $\mathrm{H}$. Hikmat hanya menampilkan tentang cara daripadi para da’i dalam menyampaikan pesan-pesan dakwah haruslah menggunakan bahasa lisan yang dilakukan dalam kontrusi bahasa tutur kepada mad'unya. Kontrusi bahasa tutur merupakan bentuk tranmisi, transaksi dan transformasi dari nilai-nilai yang sesuai dengan ajaran Islam. Sedangkan fokus penelitian yang dilakukan peneliti ini terletak pada karakteristik pesan dakwah secara universal yang didalamnya juga terdapat peran da'i.

\section{Pesan dakwah yang diproduksi pada acara dialog agama islam di radio Republik Indonesia Kabupaten Jember}

Pesan adalah sesuatu yang disampaikan pengirim kepada penerima. ${ }^{17}$ Pesan berarti perintah, nasihat, permintaan, amanat yang disampaikan lewat orang lain. ${ }^{18}$ Pesan juga memiliki arti bahwa setiap pemberitahuan, kata, atau komunikasi baik lisan maupun tertulis, yang dikirimkan dari satu orang ke orang lain. ${ }^{19}$

Sedangkan dakwah adalah proses penyampaian informasi atau pesan dari seseorang atau sekelompok orang kepada seseorang atau sekelompok orang lainnya yang bersumber

\footnotetext{
${ }^{17}$ Hafied Cangara, Pengertian Ilmu Komunikasi, (Jakarta: Raja GrafindoPersada,1998),23.

${ }^{18}$ Kbbi.web.id (31 Maret 2018)

${ }^{19}$ https://id.m.wikipedia.org/wiki/pesan. (31 Maret 2018)
} 
dari al-Quran dan hadist dengan menggunakan lambang-lambang baik secara verbal maupun nonverbal dengan tujuan untuk mengubah sikap, pendapat atau prilaku orang lain yang lebih baik sesuai ajaran Islam, baik langsung secara lisan maupun tidak langsung melalui media. ${ }^{20}$

Pengertian tentang pesan dakwah menurut kesimpulan para pakar tersebut adalah nasihat yang disampaikan oleh orang lain kepada invidu/kelompok dengan tujuan mendapatkan kebaikan. Pesan dakwah yang diberikan bersumber dari al-Qur'an dan Hadist yang bermaksud mengubah sikap, pendapat atau prilaku orang lain menjadi lebih baik.

Sedangkan pesan dakwah yang disampaikan oleh para da'i, dalam acara Dialog Agama Islam di Radio Republik Indonesia Kabupaten Jember, telah sesuai dengan apa yang dimaksud dengan pemahaman pesan dakwah di atas, yakni menyampaikan informasi atau pesan kepada masyarakat pendengar yang bertujuan untuk mengubah sikap, pendapat atau prilaku seseorang/kelompok yang berlandaskan al-Quran dan Hadits.

Menurut Abdul Basit dalam bukunya yang berjudul Filsafat Dakwah. Pesan dakwah adalah apa yang disampaikan di dalam proses kegiatan dakwah. Ada tiga dimensi yang saling terkait dengan istilah pesan dakwah. ${ }^{21}$ Pertama, pesan dakwah menggambarkan sejumlah kata atau imajinasi tentang dakwah yang dieskpresikan dalam bentuk kata-kata. Pada konteks ini pesan dakah mengandung dua aspek yaitu isi pesan (the content of the message) dan lambang (symbol). Isi pesan adalah pikiran, sedangkan lambangnya adalah kata-kata atau bahasa. Tanpa bahasa, pikiran sebagai isi pesan tidak mungkin didakwahkan. Oleh karena itu, bahasa melekat pada pikiran sehingga bahasa tidak mungkin dilepaskan dari pikiran. Tegasnya, orang berpikir dengan bahasa.

Kedua, pesan dakwah berkaitan dengan makna yang dipersepsi atau diterima oleh seseorang. Makna merupakan proses aktif yang diciptakan dari hasil kerja sama antara sumber (pengirim pesan) dengan penerima pesan, pembicara dengan pendengar, atau penulis dengan pembaca. Pemahaman terhadap makna apa yang akan disampaikan dan bagaimana menyampaikan makna kepada orang lain akan membantu diri kita dalammemaksimalkan pengelolaan pesan yang verbal maupun non verbal. Makna tidak bergantung pada pesan saja, melainkan juga pada interaksi antara pesan dengan pemikiran dan perasaan penerima pesan. Sementara, pemikiran dan perasaan penerima pesan dibangun di atas lingkungan sosial dan budaya yang bisa jadi berbeda-beda. Kata-kata tidak boleh mengandung makna, manusialah yang menciptakan makna. Konsekuensi logisnya,

${ }^{20}$ Wahyu Ilahi, Komunikasi Dakwah, (Bandung: PT Remaja Rosdakarya, 2010),24.

${ }^{21}$ Abdul Basit, Filsafat Dakwah,...140. 
untuk menemukan makna, tidak cukup hanya mengkaji kata-katanya saja, tetapi perlu melihat siapa yang memberikan makna tersebut. apakah pemberi makna tersebut seorang yangkonservatif, moderat atau liberal, akan melahirkan makna yang berbeda-beda di antara mereka.

Sebagai contoh sederhana, kata jihad secara bahasa mengandung arti bersungguhsungguh baik dalam menciptakan karya (ijtihad), beribadah (mujahadah), maupun berjuang (mujahid). Kata jihad tersebut apabila dimaknai oleh seorang yang memiliki pemikiran yang liberal dan dibentuk oleh lingkungan yang cenderung ideologis dan militan, maka jihad bisa diartikan dengan berjuang melawan kemungkaran melalui perang suci dan bahkan rela jiwanya dikorbankan untuk mati syahid. Radikalisme dan kekerasan yang mengatasnamakan agama bisa muncul, salah satunya akibat dari pemaknaan ajaran agama yang menyimpang dari makna yang sesungguhnya.

Ketiga, penerima pesan dakwah yang dilakukan oleh mad'u atau objek dakwah. Semua pesan dakwah memiliki peluang terbuka untuk dimaknai dan dipahami secara berbeda oleh penerima yang berbeda. Meskipun demikian, ada kesepakatan bersama (memorandum of understanding) antara pengirim dan penerima yang memungkinkan proses dakwah terjadi. Dari pernyataan tersebut dapat dipahami bahwa proses penerimaan pesan dakwah tidak bisa mencapai angka 100\%. Banyak faktor yang bisa menyebabkan pesan dakwah tidak bisa diterima sepenuhnya oleh mad'u, di antaranya karena faktor psikologis penerima pesan, situasi, kemampuan pengirim pesan, dan waktu penyampaian.

Berdasarkan penjelasan di atas, pengertian pesan dakwah tidak bisa dipisahkan dari ketiga dimensi tersebut. Pesan dakwah tidak hanya mengandung kata-kata saja, tetapi juga mengandung makna dan dimensi penerimaan pesan dakwah oleh mad'u. Selanjutnya, pesan dakwah tidak hanya bersifat verbal saja, tetapi juga bersifat non-verbal. Seorang penulis yang merangkai kata-kata yang mengandung nilai-nilai Islam dalam tulisannya merupakan pesan dakwah yang bersifat non-verbal. Begitu juga, seorang aktivis pergerakan yang membangun komunitasnya dan memberikan contoh dalam pengembangan keterampilan yang bermanfaat bagi masyarakat dalam mendekatkan diri kepada Tuhan dapat diklasifikasikan sebagai da'i yang melaksanakan pesan dakwah secara non-verbal.

Pesan disampaikan melalui dialog interaktif yang memungkinkan bagi pendengar menyampaikan pertanyaannya kepada narasumber atau da'i. Hal ini sesuai dengan jenisjenis pesan yang dibahas pada kajian teori, bahwa agar pesan dapat diterima dari pengguna satu ke pengguna lain, proses pengiriman pesan memerlukan sebuah media perantara agar pesan yang dikirimkan oleh sumber (source) dapat diterima dengan baik oleh penerima 
(receiver). Dalam proses pengiriman tersebut, pesan harus dikemas sebaik mungkin untuk mengatasi gangguan yang muncul dalam transmisi pesan, agar tidak mengakibatkan perbedaan makna yang diterima oleh penerima pesan. ${ }^{22}$

Menurut peneliti, bahwa kajian teori Abdul Basith tersebut telah diterapkan dalam acara dialog interakit pada program Dialog Agama Islam di Radio Republik Indonesia Kabupaten Jember. Dimana dakwah dilakukan melalui via udara yang dikemas dalam dialog interaktif, untuk memberikan umpan balik kepada pendengar atas apa yang disampaikan da'i.

\section{Karakteristik pesan dakwah pada program dialog agama islam di radio Republik Indonesia Kabupaten Jember}

Menurut istilah (terminologi) sebagaimana disimpulkan oleh para pakar dakwah, ialah meliputi pengertian yang bersifat pembinaan dan pengembangan yakni upaya mengajak umat manusia ke jalan Allah SWT, memperbaiki situasi menjadi lebih baik untuk mencapai kebahagiaan dunia dan akhirat. ${ }^{23}$

Dakwah sebagai sarana atau media pembumian nilai-nilai Islam, sebagaimana diuraikan oleh banyak pakar dakwah, mengambil bentuk dalam tiga karakteristik. Pertama, rabbaniyah (ketauhidan). Kedua, syumuliyah (komperehenship). Ketiga, alamiyah (universal). ${ }^{24}$

a. Rabbaniyah.

Sejatinya diderivasi langsung dari prinsip monoteisme yang sering disinggung dalam banyak bagian kitab suci al-Qur'an. Demikian, karena pada hakikatnya meminjam bahasa Ilyas Ismail dan Prio Hotman, dakwah merupakan "perpanjangan tangan" dari ajaran Islam. ${ }^{25}$ Dengan kata lain, dakwah merupakan instrumen bagaimana konsep Islam yang berupa ide atau pendapat diterapkan atau diwujudkan dalam tatanan kehidupan masyarakat praktis. Oleh karenanya, dakwah harus memiliki karakteristik serupa dengan Islam sebagai paradigmanya. Dalam hal ini, tauhid (ketuhanan) sebagai pondasi dari dakwah itu sendiri.

Tauhid sebagai pondasi dakwah pada intinya menghendaki agar manusia sebagai objeknya kembali kepada kepribadian sejati yang masih murni. Hal ini mengasumsikan bahwa manusia secara asal-usul adalah berkepribadian tauhid. Hal ini dapat dilihat dari pernyataan kitab suci al-Qur'an sebagai berikut;

${ }^{22}$ https://id.m.wikipedia.org/wiki/pesan. (29 Juni 2018)

23 A. Ilyas Ismail, Paradigma Dakwah Sayyid Qutub; Rekonstruksi Pemikiran Dakwah Harakah, (Jakarta: Penamadani,2006), 136.

${ }^{24}$ Abdullah Nasih Ulwan, Silsilah Madrasah al-Du'at,(Kairo: Dar al-Hadits, 2004),16.

${ }^{25}$ Ilyas Ismail dan Prio Hotman, Filsafat Dakwah: Rekayasa Membangun Agama dan Peradaban Islam,(Jakarta:

Prenada Media,2011),59. 
"Dan (ingatlah), ketika Tuhanmu mengeluarkan keturunan anak-anak Adam dari sulbi mereka dan Allah mengambil kesaksiaan terhadap jiwa mereka (seraya berfirman): "Bukankah Aku ini Tuhanmu?" Mereka menjawah: "Betul (Engkau Tuhan kami), kami menjadi saksi." (Kami lakukan yang demikian itu) agar di hari kiamat kamu tidak mengataka: "Sesungguhnya kami (bani Adam) adalah orangorang yang lengah terhadap ini (keesaan Tuhan)". (QS. Al-A'raf:172)

Sebagai asal-usul kepribadian manusia, tauhid dalam paradigma dakwah dengan demikian menjadi orientasi atau basis segala tindakan dan kebijakan-kebijakan dakwah. Ini bisa dimaknai bahwa poros setiap kegiatan dan tindakan dakwah dipastikan berujung pada usaha mentauhidkan manusia.

Mentauhidkan manusia dalam pandangan dakwah berarti memanusiawikan manusia itu sendiri sesuai dengan kepribadian asalnya, fitrahnya. Kepribadian yang menyimpang dari kemanusiawian manusia (the humanisties of humankind). Bagi dakwah yang bertujuan merealisasikan watak ke"rahmatan lil'alamin"an Islam, penyimpangan watak dasar manusia dari fitrahnya adalah sebuah problem besar yang perlu ditindaklanjuti. ${ }^{26}$

Menurut Ismail al-Faruqi, persoalan-persoalan kemanusiaan yang timbul sejatinya bertolak dari persoalan kemonoteisan ini. penympangan dari monoteisme, sebagaimana diungkap juga oleh cendekiawan Nurkholis Majid, menyebabkan timbulnya kesewenang-wenangan dan kezaliman dalam bidang politik, ketidak-adilan dalam bidang hukum, kecurangan bisnis dalam bidang ekonomi, dan kebiadaban dalam bidang sosial. dakwah dengan karakteristik tauhidnya, dengan demikian berusaha melalui berbagai upaya mengentaskan persoalan kemanusiaan seperti di atas dengan pertama-tama mencabut akar persoalannya, yakni ketidaktauhidan - kemusyrikan. ${ }^{27}$

b. Syumuliyah (comprehensive)

Sebagaimana disebutkan di atas, bahwa karakteristik dakwah berangkat dari karekteristik Islam itu sendiri. Selain mendasarkan kepada tauhid, Islam sebagai sebuah konsep ilahiah yang bermaksud menuntun kehidupan manusia sesuai dengan kehendak Tuhan, juga memiliki karakteristik serba meliputi (syumuliyah/comprehensive). Maksudnya, karakteristik Islam dan kemudian karakteristik dakwah berorientasi bagaimana caranya menderivasikan konsep ilahiah tersebut dalam semua aspek kehidupan. Dengan kata lain, Islam dan kemudian dakwah berkarakteristik ekses di setiap segi kehidupan tersebut. Karakteristik syumuliyah dalam dakwah lebih layak dimaknai sebagai penetrasi

\footnotetext{
${ }^{26}$ Ismail Raji al-Faruqi, Al-Tauhid: Its Implication For Thougt and Life, (Virginia: The International Institute of Islamic Thought, 1992),17-18.

${ }^{27}$ Ismail Raji al-Faruqi, Al-Tauhid: Its Implication For Thougt and Life, ...18.
} 
nilai-nilai moral atau meminjam bahasa yurispredensi Islam - maqashid al-syariah terhadap penentuan kebijakan atau pembuatan aturan hidup bermasyarakat. ${ }^{28}$

Hal tersebut sangat jelas jika kita kaitkan dengan konsep dakwah yang dilakukan Wali Songo dengan metode komprominya yang tidak bermaksud menerapkan ajaran Islam Arab ansich dalam budaya masyarakat Indonesia, khususnya Jawa. Melainkan lebih fokus kepada bagaimana cara memasukkan dan meleburkan pesan-pesan moral Islam atau tujuan syari'at Islam ke dalam budaya masyarakat. Walaupun secara dhahir terlihat kontras dengan Islam yang berasal dari Timur Tengah. Setiap budaya yang melekat pada pelbagai aspek kehidupan masyarakat nusantara dan telah mengadopsi prinsip-prinsip moral atau tujuan syari'at Islam berarti telah mengalami proses dakwah. Artinya, karakteristik dakwah syumuliyah memiliki intens untuk masuk ke segala sendi kehidupan masyarakat secara esensial, bukan literal dan parsial. $^{29}$

c. Alamiyah (universal)

Alamiyah (unversalisme) sebagai karakteristik dakwah bermakna bahwa dakwah itu memiliki cakupan luas yang tidak terbatas waktu maupun teritorial. Karakteristik ini lahir dari watak dasar universalisme Islam itu sendiri dalam banyak teks-teks hadis yang dijelaskan bahwa tujuan kehadiran Nabi Muhammad SAW dan ajaran Islamnya tidak ditujukan hanya untuk ras manusia tertentu saja, dalam hal ini Arab. Al-Qur'an menegaskan:

"Dan Kami tidak mengutus kamu, melainkan kepada umat manusia seluruhnya sebagai pembawa berita gembira dan sebagai pemberi peringatan, tetapi kebanyakan manusia tiada mengetahu." (QS. Saba':28).

Dalam hadis mislanya Nabi Muhammad SAW menjelaskan, bahwa ia diutus tidak terbatas kepada ras tertentu. Beliau bersabda, yang artinya;

"Aku telah dikaruniai lima hal yang tidak pernah diberikan kepada seorangpun (Nabi) sebelum aku, dan aku tidak mengatakan hal ini sebagai kesombongan. Aku diutus ke setiap manusia baik yang berkulit hitam maupun merah, maka tidaklah dari ras kulit merah dan ras hitam yang (memeluk Islam) masuk ke dalam golongan umatku kecuali dia memang termasuk dari mereka (umatku)" (HR. Ahmad) ${ }^{30}$

Dengan karakteristik Islam seperti ini maka dakwah juga memiliki karakteristik yang universal. Sampai disini timbullah persoalan baru yaitu keragaman konteks sosial budaya masyarakat sebagai sasaran dakwah dan tunggalnya prinsip-prinsip dakwah. Tugas da’i dalam hal ini bagaimana caranya menyelaraskan prinsip dakwah yang tunggal itu dalam konteks sosial budaya yang beraneka ragam. Wali Songo lebih cenderung

${ }^{28}$ Dedi Ismatullah, Sejarah Sosial Hukum Islam, (Bandung: Pustaka Setia,2011),63.

${ }^{29}$ Syukron378.blogspot.co.id/2013/05/dakwah-dan-karakteristiknya.html?m=1 (7 April 2018)

${ }^{30}$ Ahmad Ibn Hanbal, Musnad Ahmad, (Mawqi al-Islam), vol. 5. h.176, hadis no. 2144 
mengambil jalan kompromistis dan adaptasionis terhadap konteks sosial budaya dan lebih sedikit mengambil bentuk-bentuk formal dalam mensosialisasikan nilai-nilai Islam.

Jika dikatikan dengan pesan dakwah yang disampaikan oleh KH. Mohammad Hasien melalui acara Dialog Agama Islam di Radio Republik Indonesia Kabupaten Jember, telah sesuai dengan pemahaman tiga karakteristik dakwah, yakni rabbaniyah (ketauhidan), syumuliyah (komprehenship) dan alamiyah (universal). Mengingat hasil observasi dan wawancara yang dilakukan peneliti, tiga unsur tersebut tercakup dalam acara Dialog Agama Islam di Radio Republik Indonesia Kabupaten Jember.

Sedangkan karakteristik pesan dakwah menurut Abdul Basit dalam bukunya yang berjudl Filsafat Dakwah, tidak membedakan secara spesifik antara karakteristik dakwah yang bersifat verbal mapun non-verbal. Karakteristik pesan dakwah menurut Abdul Basit tidak sama dengan pesan dalam komunikasi. Oleh kareanya, perlu dikenali karakteristik pesan dakwah, antara lain; ${ }^{31}$

a. Mengandung Unsur Kebenaran

Karakteristik pertama dan utama dalam pesan dakwah Islam adalah adanya kebenaran dalam setiap pesan yang disampaikannya. Berbeda dengan komunikasi dimana dalam prosesnya bisa mengandung unsur yang tidak benar atau negatif. Sebagai contoh sederhana, A seorang mahaisiswi ingin mencelakai B (seorang yang telah merebut pacarnya). A kemudian mengajak temannya untuk bekerja sama dalam aksi mencelakai si B. Kemudian teman-temannya setuju dan melakukan aksi sesuai degan rencana yang telah disepakati. Ajakan yang dilakukan oleh si A dapat disebut sebagai pesan komunikasi, tetapi tidak bisa disebut sebagai pesan dakwah.

Kebenaran yang dimaksud dalam pesan dakwah adalah kebenaran yang bersumber dari Allah Swt., sebagaimana dinyatakan dalam firman-Nya "kebenaran itu datangnya dari Tuhanmu, sebab itu jangan sekali-kali engkau termasuk orangorang yang ragu" (QS Al-Baqarah [2]:147). Kebenaran yang bersumber dari Allah tersebut berwujud dalam bentuk rangkaian ayat-ayat yang terdapat dalam AlQur'an. Jadi Al-Qur'an merpakan sumber kebenaran mutlak yang perlu disampaikan oleh da’i kepada manusia. Jika ada kebenaran-kebenaran di dunia yang bersifat relatif dan pragmatis bisa dijadikan pesan dakwah selama kebenaran tersebut tidak bertentangan dengan kebenaran yang ada di dalam Al-Qur'an.

${ }^{31}$ Abdul Basit, Filsafat Dakwah,...142. 
Berdasarkan hasil penelitian yang dilakukan terhadap KH. Hasien yang merupakan da'i dalam acara Dialog Agama Islam di Kabupaten Jember, bahwasanya pesan dakwah yang disampaikan mengandung unsur kebenaran dengan mengajak kepada kebaikan dan mencegah dari kemungkaran.

b. Membawa Pesan Perdamaian

Sesuai dengan namanya Islam yang berkata dasar salam artinya damai. Perdamaian menjadi unsur penting yang harus dikembangkan dalam penyampaian pesan dakwah. Menurut Hassan Hanafi, perdamaian bukan sekedar hukum internasional antara negara-negara adidaya. Perdamaian berawal dari individu kemudian berkembang ke keluarga dan kehidupan sosial. ${ }^{32}$ Ucapan assalamu'alaikum (semoga kedamaian untuk kalian) yang diucapkan seorang merpakan pesan dakwah yang terus digulirkan oleh setiap individu Muslim. Mengucapkan salam ketika memasuki rumah merupakan ajaran untuk menjaga privasi dan perdamaian di rumah. Rumah merupakan salah satu privasi yang harus dilindungi. Dilarang memasuki tanpa perkenan dari pemiliknya. Memaksa masuk, memata-matai, merampok dan segala bentuk tindakan yang melanggar batas privasi tersebut adalah bertentangan dengan perdamaian.

Tuhanpun mengucapkan salam kepada Nabi. Dengan pengucapan salam tersebut, Tuhan menyatakan bahwa essensi dari pengutusan Nabi adalah untuk perdamaian. Para Nabi dan Rasul menyebarkan Islam yang mengandung nilai-nilai perdamaian. Janganlah kita kotori ajaran Islam dengan menunjukkan perilakuperilaku yang bertentangan dengan nilai-nilai perdamaian. Kekerasan, radikalisme, terorisme, peperangan, dan pertikaian merupakan perilaku-perilaku yang bertentangan dengan nilai-nilai perdamaian. Kekerasan, radikalisme, terorisme, peperangan, dan pertikaian merupakan perilaku-perilaku yang harus dihindari dalam proses penyampaian pesan dakwah. Tanamkan nilai-nilai perdamaian dalam diri, keluarga, kelompok, dan masyarakat kita.

Dalam menanggapi pertanyaan para pendengar, jawaban yang dikemukakan KH. Hasien selalu mengedepankan atau menonjolkan persamaan, bukan perbedaan. Sehingga masyarakat pendengar memahami bagaimana menghormati dan menyikapi perbedaan yang ada. Hal ini akan berdampak kepada kondusivitas di masyarakat yang tak lepas dari perbedaan, baik memahami agama ataupun lainnya.

${ }^{32}$ Hassan Hanafi, Agama, Kekerasan, dan Islam Kontemporer, (Yogyakarta: Jendela,2001),129. 
c. Tidak Bertentangan Dengan Nilai-nilai Universal

Pesan dakwah hendaknya disampaikan dalam konteks lokalitas dari mad'u yang menerima pesan. Dengan cara tersebut, pesan dakwah akan mudah diterima oleh masyarakat karena sesuai dengan kebutuhan dan keinginan masyarakat. Persoalan yang muncul ke permukaan ketika ajaran Islam diyakini sebagai ajaran yang bersumber dari Arab sehingga lokalitas 'ke-Arab-an” menjadi sesuatu yang dianggap universal dan mesti diikuti oleh masyarakat di luar Arab. Seakan-akan Islam tidak memerhatikan perbedaan wilayah dan latar belakang masyarakat yang menjadi objek dakwah.

Dalam hal ini kita perlu membedakan antara sumber dengan proses penyampaian dan pemaknaan pesan dakwah. Dalam perspektif sumber pesan dakwah, maka Islam diyakini sebagai ajaran yang bersumber dari Tuhan dan diyakini sebagai ajaran yang universal. Al-Qur'an sebagai wahyu yang diterima oleh Rasulullah merupakan sumber ajaran universal, bukan hanya untuk orang Islam Arab, tetapi diperuntukkan juga untuk orang di luar Arab. Dengan perkataan lain, pesan dakwah berlaku secara universal untuk semua manusia di dunia.

Ayat Al-Qur'an yang berbunyi

"dan hendaklah ada di antara kamu segolongan umat yang menyeru kepada kebajikan, menyuruh kepada yang ma'ruf dan mencegah dari yang munkar; merekalah orang-orang yang beruntung" (QS: Ali Imran 104)

Merupakan dalil yang mempertegas bahwa pesan dakwah yang universal (alkhair) hendaknya disampaikan dalam konteks lokalitas dengan cara yang al-ma'ruf (pandangan umum masyarakat yang sejalan dengan al-khair). Dalam menyampaikan al-ma'ruf, prinsip dasar yang dipegang adalah dalil Al-Qur'an surat At-Taghabun (64) ayat 16 yang berbunyi

"Maka bertakwalah kami kepada Allah menurut kesanggupanmu" dan berpegang pada kaidah "mempertahankan nilai lama yang baik dan mengambil nilai baru yang lebih baik. ${ }^{33}$

Persoalan-persoalan yang disampaikan oleh para pendengar baik melalui telepon, sms atau media sosial lainnya dijawab oleh da'i dengan menggunakan pijakan sumber hukum Islam. Semisal dengan pertanyaan hukum khomer. Khomer adalah sari kurma yang diendapkan selama bertahun-tahun, sementara di Indonesia tidak ada pohon kurma, untuk menjawabnya harus berpijak kepada sumber hukum Islam yakni Al-Qur'an dan Hadits.

\footnotetext{
${ }^{33}$ Quraish Shihab, Tafsir Al-Misbah, Juz 2, (Jakarta: Lentera Hati,2008),176.
} 
d. Memberikan Kemudahan Bagi Penerima Pesan

Memberikan kemudahan dalam menyampaikan pesan dakwah merupakan sesuatu yang dianjurkan dan bahkan menjadi tujuan syariat Islam, sebagaimana dijelaskan dalam Al-Qur’an

"Allah menghendaki kemudahan bagimu dan tidak menghendaki kesukaran bagimu" (QS Al-Baqarah [2] 185) dan sabda Nabi Muhammad Saw. "mudahkanlah dan janganlah kamu mempersulit" (HR. Muttafaq 'alaih).

Memudahkan dalam pesan dakwah tidak diartikan memilih-milih hukum yang ringan-ringan saja dari berbagai pendapat ulama fikih (melakukan talfiq). Memudahkan yang dimaksud sebagai kemudahan dalam pengamalan ajaran agama yang tidak bertentangan dengan nash-nash dan kaidah syariat Islam.

Respons umat dalam menerima ajaran akan lebih bergairah dan termotivasi untuk melakukannya manakala pesan dakwah yang disampaikan mudah dipahami dan dapat dilaksanakan. Apalagi kecenderungan masyarakat modern yang senang dengan hal-hal yang praktis, sederhana dan berfungsi dalam membantu mempermudah kehidupan yang dijalaninya. Buku-buku motivasi, pembelajaran agama melalui media elektronik, doa-doa harian yang dikemas dalam buku saku, petunjuk dalam keluarga, dan lain sebagainya merupakan contoh-contoh kemasan pesan dakwah yang banyak mendapatkan respons umat.

Pada konteks ini, da'i dituntut untuk lebih berinovasi dan berkreasi dalam menciptakan materi-materi dakwah yang lebih menarik dan inklusif. Da’i perlu terus meningkatkan kompetensi dan profesionalismenya dengan terus belajar, membuka pikiran secara terbuka (open minded), dan mau menerima berbagai informasi yang berkembang pada saat ini.

Dalam memberikan tausiyahnya, KH. Hasien menyampaikan dengan menggunakan beberapa bahasa yakni bahasa Jawa, Madura dan Indonesia. Ketiga bahasa tersebut dikuasai oleh KH. Hasien. Dan bahasa yang digunakan adalah bahasa tutur yang santun dan simple dengan menghindari kata-kata yang sulit.

e. Mengapresiasi Adanya Perbedaan

Ada pengalaman menarik ketika ada seorang da’i menyampaikan pesanpesan dakwahnya dengan lantang dan penuh semangat. Materi yang disampaikan berkisar pada praktik keberagaman (tradisi) yang biasa dilakukan oleh kalangan Nahdliyin. Da'i tersebut kurang mengenal mad'u dan kurang mampu membaca situasi di mana jamaah tersebut berada. Ternyata jamaah yang diajak umumnya kalangan Muhammadiyah. Akhirnya, apa yang disampaikan oleh da’i tersebut 
kurang mendapatkan tanggapan positif dari para jamaah. Meraka hanya diam dan terkadang mengabaikan apa yang disampaikan oleh da’i tersebut.

Selain itu, ada juga juga seorang da’i yang mengatasnakaman kelompok salafiyah atau kaum modernis menyampaikan khutbah Jumat atau pengaiian yang isinya menyalahkan pendapat atau paham yang ada di luar kelompoknya. Bahkan menjelek-jelekkan dan menyatakan bahwa apa yang dilakukan di luar kelompoknya adalah sesat dan masuk neraka.

Pesan dakwah yang disampaikan oleh kedua da’i tersebut kurang mengapresiasi adanya perbedaan paham dan keyakinan yang dianut oleh para jamaah. Dalam realitas tidak bisa dipungkiri bahwa setiap individu atau setiap Muslim diciptakan oleh Allah berbeda-beda. Tidak ada di dunia ini manusia yang memiliki kesamaan antara satu dengan lainnya. Selain itu, perbedaan juga bisa terbentuk karena perbedaan latar belakang sosial, wilayah, afiliasi politik, tingkat partisipasi dalam masyarakat dan organisasi keagamaan yang dipilihnya.

Islam melarang ummatnya untuk melakukan pemaksaan dalam beragama (QS Al-Baqarah [2]: 256), bercerai berai atau berpecah belah (QS Al-Imran [3]: 103), berburuk sangka (QS Al-Hujurat [49]: 10-13), dan lain sebagainya. Perbedaan yang ada hendaknya dijadikan sebagai upaya untuk saling melengkapi kekuragan masing-masing, saling kenal mengenal dan untuk memudahkan pekerjaan. Perbedaan merupakan sunnatullah yang harus dikelola dengan baik. Oleh karena itu, tugas seorang da'i bersama masyarakat dalam mengelolala perbedaanperbedaan yang ada sehingga menjadi kekuatan-kekuatan yang dapat meningkatkan kualitas umat dan kesejahteraan masyarakat.

KH. Hasien sangat menjunjung tinggi perbedaan. Hasil pengamatan peneliti dalam setiap tausiyahnya, tidak pernah membenarkan pemahaman Nahdlatul Ulama kepada kalangan Muhammadiyah, pun sebaliknya. Meskipun KH. Hasien sendiri adalah seorang yang berpaham Nahdlatul Ulama. Ia juga tidak memperuncing perbedaan dengan memberikan tausiyah ataupun jawaban tentang perbedaan, justru ia lebih menonjolkan persamaanya.

\section{KESIMPULAN}

Berdasarkan data-data dan temuan penelitian, maka dapat disimpulkan hal-hal sebagai berikut: Pesan dakwah yang dikemas dalam dialog interaktif melalui acara Dialog Agama Islam di Radio Republik Indonesia Kabupaten Jember, mendapatkan respon yang baik dari 
masyarakat. Hal ini terbukti, dengan jumlah tren pendengar serta pendengar yang merespon saat acara Dialog Agama Islam berlangsung. Respon masayarakat ini tidak hanya melalui jalur telepon, namun juga melalui sms, what's upp dan facebook.

Permasalahan-permasalahan yang disampaikan oleh masyarakat mencakup masalah ibadah, ekonomi, hubungan suami istri, sampai kepada masalah narkoba dan bagaimana memahami ikhtilaf atau perbedaan yang ada di masyarakat. Masyarakat tampak antusias dalam memberikan responnya, sampai-sampai ada yang datang ke rumah $\mathrm{KH}$. Hasien, yang bertindak sebagai da’i dalam acara ini, guna memperoleh solusi yang tidak bisa tersampaikan melalui acara dialog tersebut.

Acara yang berlangsung sejak pukul 05.00 sampai 06.00 Wib ini, memungkinkan pendengar menikmatinya, mengingat waktu tersebut merupakan waktu santai bagi sebagian orang, sedangkan bagi ibu-ibu rumah tangga maupun karier adalah waktu mempersiapkan sarapan bagi keluarga. Sementara radio, merupakan media efektif yang bisa didengarkan dimana saja, baik saat berada di kamar, di dapur, di jalan, bahkan di dalam kendaraan.

\section{DAFTAR PUSTAKA}

Arikunto, 1998, Prosedur Penelitan Suatu Pendekatan Praktek, Rineka Cipta, Jakarta.

Biagi, Shirley, 2010, Media/Impact, Salemba Humanika, Jakarta.

Bungin, Burhan, 2006, Sosiologi Komunikasi, Prenada Media, Jakarta.

Bungin, Burhan. 2008. Konstruksi Sosial Media Massa, Kencana, Jakarta.

Dewan Pers, 2006, Membangun Kapasitas Media, Sekretariat Dewan Pers, Jakarta.

Din Wahid dan Jamhari Makruf “Suara Salafisme” Prenamedia Grup, Jakarta.

Hefni, Harjani, 2015, Komunikasi Islam, Prenada Media, Jakarta

Ishaq, Ropingi, 2016, Pengantar Ilmu Dakwah, Madani, Malang.

Ks, Usman, 2009, Ekonomi Media, Ghalia Indonesia, Bogor.

Sugiono, 2011, Metode Penelitian Kualitatif Kuantitatif dalam R\&D, Alfabeta, Bandung

Syah, Sirikit, 2012, Watch the Dog!, RMBOOKS, Jakarta.

Uchjana, Onong, 1991, Radio Siaran, Mandar Maju, Bandung

Uchjana, Onong, 2014, Metode Penelitian Komunikasi, Remaja Rosdakarya, Bandung.

Wibowo, Wahyu, 2009, Menuju Jurnalisme Beretika, Kompas, Jakarta.

Yanuar Nugroho, Muhammad Fajri Siregar, Shita Laksmi, 2013, Memetakan Kebijakan Media di Indonesia, Centre for Innovation Policy and Governance. Jakarta.

\section{Sumber Jurnal/internet.}

digilib.iain-palangkaraya.ac.id/ 
Diana

digilib.uinsby.ac.id/20159

fitrianimaduddin, dalam blog khusus cak Rian.

https://id.m.wikipedia.org/wiki/pola

m.rri.co.id/profil.html. 